\title{
KŪRYBINIO EKSPERIMENTO SAMPRATOS ARCHITEKTŪROJE
}

\author{
Tomas Grunskis \\ Architektūros pagrindu ir teorijos katedra, Vilniaus Gedimino technikos universitetas, \\ Pylimo g. 29/Traku g. 1, 01132 Vilnius, Lietuva \\ El.paštas grunskis@gmail.com \\ Iteikta 20100906
}

Santrauka. Straipsnyje analizuojamos esminès kūrybinio eksperimento sampratos architektūroje. Apžvelgiami pagrindiniai mokslinio ir meninio eksperimento principai, konceptai juos charakterizuojant bei lyginant tarpusavyje, detalizuojant tiek esminius skirtumus, tiek ir logines sąsajas tarp vienų ir kitų. Taip pat tekste plačiai analizuojamas kūrybinio eksperimento reiškinys architektūroje, aptariant ir mokslinės, ir meninès sričių itakas jam, jo specifikas ir ypatumus.

Reikšminiai žodžiai: eksperimentinè architektūra, kūrybinis eksperimentas, samprata.

\section{Ivadas}

Analizuojant architektūrinius kūrybinius eksperimentus, susiduriama su labai plačiu spektru reiškinių ir pavyzdžių, kuriuos nèra lengva sistemingai aptarti. Tai manifestai (manifestoes) (Betsky, Adigard 2000'; Jencks, Kropf $1997^{2}$ ), išreiškiantys naujausias ir nebūtinai architektūrines idejjas; utopinés bei distopiness vizijos (More 2003, Boullee, Le Corbusier 1987), išreiškiančios socialines ịtampas ir problemas tiek duotuoju, tiek ir prognozuojamu laiku; tai ir požiūriai (approaches) (Le Corbusier 1986; Knack, Klein 2008), kuriais remiantis sprendžiamas vienokio ar kitokio pobūdžio metodo ar unikalaus sprendinio klausimas, šie du siejasi su vienokio ar kitokio pobūdžio architektūriniais atradimais (Leopold 2005), kai surandamas sprendimas ar principas, kurie nebuvo naudojami iki tol; tai taip pat ir procesai bei principai (Terzidis 2006, Fischer 2000), kurie veikia ir kartais net formuoja architektūrą

\footnotetext{
1 Aaron Betsky ir Adigard knyga Architecture must Burn tiesiogiai buvo ịvardinta kaip manifestas apie architektūrą už pastato ribų. Tai aiški referencija ị platesnị architektūros veiklos kontekstą bei jos kultūriškumą. Pats leidinys, nors ir tradicinès knygos pavidalo, savo turiniu ir vidine kompozicija bei struktūra tikrai gali būti laikomas ekperimentu.

2 Jencks ir Kempf knygoje Theories and Manifestoes of Contemporary Architecture aptariami svarbiausi architektūriniai manifestai ir teorijos, kurių nemažas kiekis gali būti laikomas eksperimentiniais.
}

bei jos išraiškas ir kurie yra reflektuojami bei išreiškiami architektūrine kalba ir be kurių šiuolaikinè architektūrinè ir urbanistine praktikos nebūtų priartejusios socialumo link. Taigi, susiduriame su labai ịvairiais sunkiai viena kategorija įvardijamais reiškiniais ir rezultatais, kurie vienaip ar kitaip siejasi su eksperimentine architektūrine kūryba ir, kaip rodo architektūros istorijos raida, ji (eksperimentinè kūryba) yra viena iš varomųjų jègų, padedančių architektūrai per ce vystytis ir keistis laike.

Šiame tekste architektūros samprata yra platesnè, nei ịprasta, architektūra suvokiama plačiąja prasme, jai priskiriant ir architektūrinę pastatų kūrybos, ir urbanistinę kūrybinę praktikas. Remiantis tokia paradigma, visos architektūrinès praktikos konceptualiai patenka ị aiškiai kultūrinị lygmenį, kuriam architektūra visada priklausè, tačiau apie kurị labai dažnai pamirštama. Šiuolaikinejje architektūrologineje literatūroje ir veikaluose dominuoja keletas pagrindinių temų: architektūros istorijos refleksijos (Traganou, Mitrasinovic 2009; Miles 2004), architektūrinių praktikų pristatymas ir kontekstualizavimas (Koolhaas, Mau, Werlemann, Sigler 1995; MVRDV 1999; Powley 1994; Betsky, Gössel 2007; Jadidio 2009; Tracing... 2006; Field 2006; Mönninger, Gössel 2010), 
išreiškiant jų vertingumą, architektūrinę kultūrą propaguojantys tekstai (From... 2008; Verb... 1999, 2005), kuriuose rašoma apie ją kur kas plačiau nei empiriniu ar didaktiniu aspektu ir kuriuose aptariami architektūros kūrybiniai procesai bei rezultatai, remiantis kur kas platesnio sociokultūrinio konteksto paradigmomis. Tokia kryptis tapo populiari pačioje XX a. pabaigoje ir XXI a. pradžioje, kai architektūros menas apskritai išgyveno labai stiprų pakilimą. İ šią sritị ir yra orientuojamas šis tekstas, kuriame siekiama atsakyti, kaip suprantamas architektūrinis eksperimentas ir koks menų bei mokslo santykis juose.

Architektūrinio eksperimento sampratų klausimas yra svarbus ir aktualus dviem aspektais. Pirma, jomis naudojamasi, kai stengiamasi suformuoti didesnes architektūrines ir kultūrines deklaracijas, kurios labai dažnai naudojamos ivairiems svarbiems kultūriniams, politiniams požiūriams deklaruoti ir formuoti, o tai labai dažna praktika pasaulinèse architektūros bienalèse ar Expo parodose. Antra, svarbi yra kultūrinè verté, nes per eksperimentinę kūrybą išreiškiamos idejos ir mintys labai dažnai perteikia socialinę plotmę bei būvius, ir tai, kaip apie architektūrą mąstoma ar suprantama konkrečiu laikotarpiu, ir tai, kokị vaidmenị jai suteikia visuomenè. Galop architektūra yra priemonè, kuria naudojasi visuomenès, norèdamos išreikšti savo sociokultūrinę būklę ir vertybes. Jos ir yra svarbios, bet pernelyg dažnai pamirštamos architektūros praktikoje.

Paminètina, kad šis tekstas yra didesnio darbo apie eksperimentinę architektūrą dalis, ir jame aptariami ne visi galimi aspektai bei klausimai.

\section{Eksperimento konceptai meninëje ir mokslinėje veikloje}

Kaip jau minèta, kūrybinio eksperimento sąvoka yra labai plati. Šis platumas yra nulemtas keleto veiksnių. Pirmasis - tai, kad kūrybiniam eksperimentui kaip ir visai meninei kūrybai yra būdingas gaivališkumas bei spontaniškumas. Antrasis yra tas, kad kūrybinius eksperimentus sunku priskirti vienai kuriai nors sričiai, ir dažniausiai tų sričių ribos sąminingai pažeidžiamos ar laužomos. Čia labai svarbus kvestionavimo elementas, kuris beveik privalomai neigia konvencionalias kūrybinių patirčių ir praktikų ribas. Pačiame konceptualiausiame lygmenyje eksperimentas grindžiamas trimis motyvais (1 pav.): prielaida (o kas, jeigu...?), galimybių plètimu (o gal įmanoma?) ir problemos sprendimu (kaip padaryti, kad...?). Visi trys demenys yra susiję su pažinimu, nes dažniausiai vyksta tikroveje arba yra realūs. Pažinimas veda prie suvokimo, kad ir su kuo jis būtų susijęs (su problemomis, aplinkybemis, reiškiniu, mechanizmais, organizacijomis, idejomis ir panašiai), o šis - prie atsakymo, jeigu toks reikalaujamas.

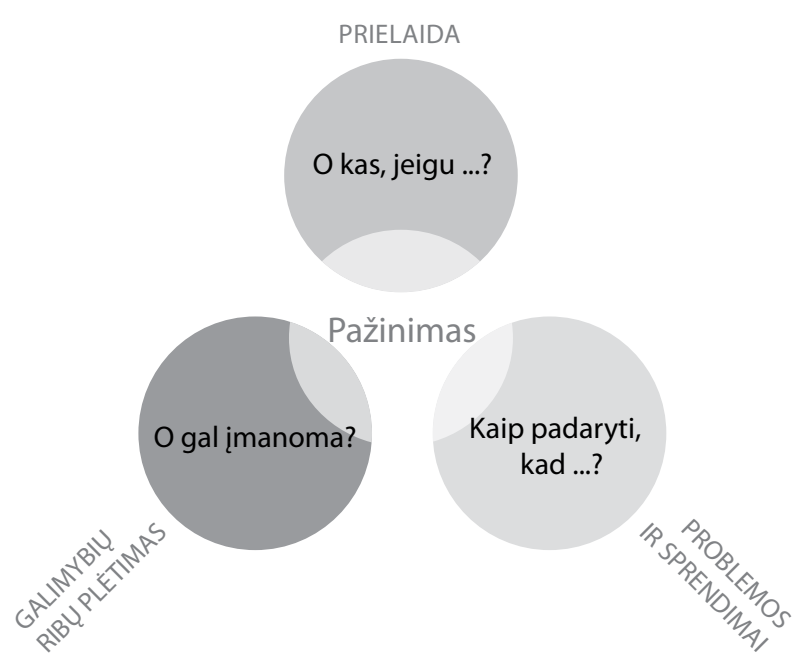

1 pav. Eksperimentinès veiklos motyvacijos

Fig. 1. Experimental activity motivation

Paprastai prie kažkokio pavadinimo pridedant žodi eksperimentinis arba eksperimentas suvokiama aiški referencija ị moksliškumą ir (mokslinius) bandymus, kurie nebūtinai bus pavykę. Pirminè žodžio eksperimeñtas [lot. experimentum - mèginimas, bandymas] reikšmé yra siejama su moksline praktika: „1. moksl. bandymas - tiriamojo reiškinio stebejimas tiksliai apskaičiuotomis sąlygomis, leidžiančiomis stebèti reiškinio eigą ir, pakartojus tas sąlygas, jị vèl atkurti“" (Tarptautinių žodžių žodynas 1985). Ir tik antra reikšmè yra „2. bandymas, mèginimas“. O žodis eksperimeñtinis aiškinamas kaip „gautas eksperimentu, juo pagrịstas, bandomasis, negalutinis", matyti aiški referencija į neužbaigtą, nors ir motyvuotą procesą. Bendresne prasme kūrybiniams eksperimentams priskirsime tai, kas tam tikru laiku suvokiama (arba yra) kaip nauja arba kas išsprendžiama nauju būdu ir keičia iki tol nusistovejjusius požiūrius - jei ne radikaliai, tai bent jau iš esmès. Susiduriame su gana dviprasmišku teiginiu, kuris skirtingose mokslo ir meno srityse gali reikšti skirtingus dalykus. Daugeliu atvejų istoriniai kūrybiniai eksperimentai vadinami būtent taip, nes jie mums atrodo turintys eksperimentui būdingų bruožų. Čia prisimintini naujieji prancūzų klasicistai vizionieriai Bullee, Ledaux ir Lequeu (Lemagny 2002; Perouse De Montclos 1974; Kaufmann 1952; Duboy 1986; Ledoux 1804), kurių kūryboje buvo daugiau nełgyvendinamų idejjų. Tačiau šis idealistinis aspektas ir perkelia jų kūrybą ị kultūrinès vertybès lygmenị, nes jie valdè ir propagavo idejas bei metodus, formulavo principus, kuriuos vèliau kiti taikè kūrybinèse praktikose. Šis aspektas, manytina, yra vienas iš svarbesnių.

Mokslinejje veikloje eksperimentas iš esmès yra suvokiamas kaip mokslinis (kartais tyrimo) metodas, 
paneigiantis arba patvirtinantis mokslinius modelius, hipotezes ar teorijas ir būdingiausias jam yra stebèjimo aspektas. Mokslineje veikloje yra keliamas arba sprendžiamas konkretus klausimas ar problema, vèliau formuluojama hipotezè ir tada eksperimentai naudojami šiai hipotezei patikrinti. Gauti rezultatai paprastai analizuojami apibendrinant, o kaip rezultatas kuriama teorija, kuri dažniausiai publikuojama tyrimų ataskaitose. Egzistuoja trys pagrindinès eksperimentu rūšys:

1. Kontroliuojami, natūralūs, arba natūriniai.

2. Stebejimu studijos.

3. Vadinamieji „lauko“ arba nelaboratoriniai ${ }^{3}$.

Visi šie eksperimentai yra nukreipti kiek galima objektyvios teisybès paieškai. Tačiau meninio eksperimentavimo logika yra visiškai kitokia. Ji skiriasi visais trimis anksčiau minètais demenimis: ir prielaida, ir principais, ir rezultatais. Mokslineje veikloje net ir darant prielaidas operuojama objektyviais faktais ir duomenimis, o meninèje eksperimentinëje veikloje prielaida gali būti abstrakti ideja, kuri nebūtinai bus objektyviai motyvuota ir nebūtinai bus skirta spręsti konkrečiai problemai ar klausimui. Meniniame eksperimente tai gali būti tiesiog naujų galimybių paieška.
Taikant principus mokslinejje veikloje eksperimentą turi būti įmanoma pakartoti ir gauti tą patị rezultatą, o tai reiškia kiek galima stabilias sąlygas. Taip pat ji privaloma pagrịsti neabejotinais empiriniais stebejimais ir tyrimais. Menineje veikloje eksperimento kartojimas yra betikslis, nes konkretus eksperimentas yra unikalus kaip ir pats meno kūrinys ir savaime yra vertybė (ypač jei jis laikomas pavykusiu), o sąlygos eksperimentuoti čia nuolat kinta, kartu rezultatai nebūtinai bus apibendrinami ar motyvuojami. Meniniame eksperimente egzistuoja gaivališkumo ir spontaniškumo plotmé, kuri ir suteikia jam meniškumo ar meninès vertès. Pagaliau mokslineje veikloje eksperimentuojant tikslingai judama kokios nors problemos sprendimo ar atradimo link bei siekiama efektyvaus jo pritaikymo, o išvados veda prie objektyvios teisybès, meninio eksperimentavimo rezultatas - kūryba - ne visada veda prie kūrinio kaip galutinio tikslo, nes tikslas gali būti ir idomus procesas, ir juo labiau ne visada siekia atsakymo ar objektyvios teisybès, nes jie gali likti grynai subjektyvūs dalykai (2 pav.). Vienas svarbus veiksnys, lemiantis meninio eksperimento kokybę, ypač kalbant apie šiuolaikinius meninius eksperimentus,

\section{$[\mathrm{Mo}+\mathrm{Me}]$}

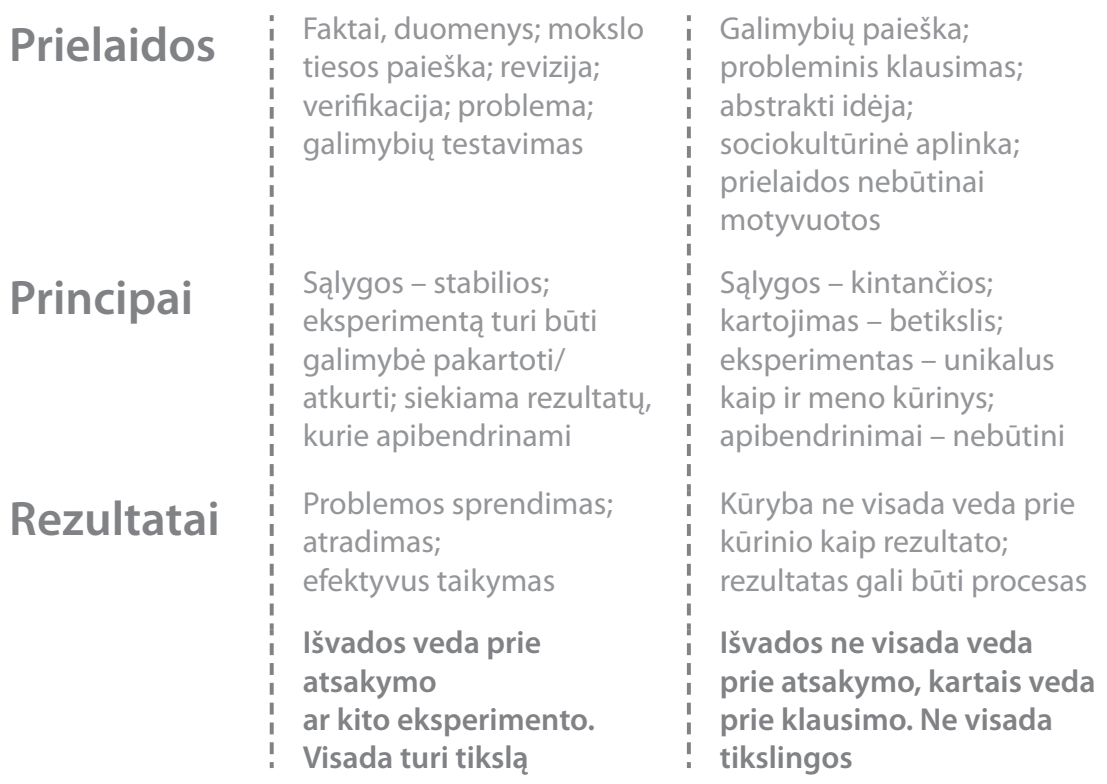

\section{[tarpdalykinis]}

2 pav. Meninio ir mokslinio eksperimento palyginimas

Fig. 2. Comparison between artstic and scientific experiments

\footnotetext{
3 Vienas iš eksperimentinio mokslo pradininkų buvo britas Francis Bacon' as, gyvenęs XVII a. Prie iškilių šio metodo plètotojų priskiriami: astronomas Galileo Galilei (1564-1642), naudojęs algebros skaičiavimo metodus ir tuo prisidejjęs prie vèles-
}

nés jos raidos iki matematinių lygčių, kurias labai produktyviai naudojo Newton'as, Maxwell'as ir Einstein'as; taip pat Antoine Lavoisier (1743-1794) - prancūzų chemikas; mikrobiologijos tèvu laikomas prancūzas Louis Pasteur (1822-1895). 
yra tarpdalykiškumas, kai kitos, galbūt net visiškai mokslinès srities informacija ar duomenys yra kūrybingai panaudojami ar interpretuojami paverčiant juos meno kūriniu, kuris naujai reflektuoja minètas žinias panaudojant meninès itaigos priemones ar net kelias meno rūšis - pavyzdžiui, vaizdo meną ir eksperimentini garsąa

\section{Architektūrinio eksperimento sampratos ir ribos}

Kūrybinio eksperimentavimo ideologijos ir patirtys neabejotinai yra vienas iš bet kurios meno ar mokslo raidos variklių (tai vienaip ar kitaip deklaruoja daugelis autorių). Nors eksperimento motyvai, procesai ir lūkesčiai mene bei moksle yra skirtingi, gauti sèkmingi rezultatai labai dažnai tampa universaliu ir visiems prieinamu palikimu, taip pat labai dažnai veikia tolesnę mąstymo kryptị skirtingose tam tikros srities plotmèse. Daugelis šiuolaikinių architektūrologų ir teoretikų konstatuoja, kad architektūra tiek sampratos (Miles 2004; Mitchel 2003; Rattenbury 2005), tiek praktikos (Hill 2006), tiek vertès požiūriu yra labai pakitęs reiškinys (Rattenbury 2005), ypač jeigu būtų lyginamas su tradicinemis (arba fundamentaliosiomis) architektūros definicijomis nuo Vitruvijaus iki Le Corbusier ir vèliau (Jencks, Kropf 1997; Глазычев 2002). Tiesa, dèsniai, kuriuos ịvardija šie fundamentalūs autoriai, visur susisieja, tačiau XXI a. pradžioje jau paaiškejo, kad ir sąvokos, ir turinio, ir proceso, ir net metodo požiūriu architektūra kaip menus bei mokslus akumuliuojanti sritis gerokai transformavosi. Ji palaipsniui tampa labai dinamišku substratu, apimančiu ir kurtuazines ir populiarias kultūrines sritis. Architektūra nebèra statinių statymo menas, kaip tai deklaravo Aaron Betsky 2008 m. Venecijos bienalèje „Architektūra už pastato ribų“ (Betsky 2008). Tikriausiai grynai tokiu menu ji niekuomet ir nebuvo, nes įvairiausiais laikais jos rezultatai reiške kur kas daugiau nei konkretus statinys. Šiandien reikia konstatuoti, kad ji yra tapusi globaliu kultūriniu fenomenu, turinčiu savą „prekinę išvaizdą“, ir taip pat konvencionalia ideologija, kuri radosi ir keitessi atliekant architektūrinius eksperimentus (kartais atrodo, kad ji yra tapusi globalia preke ar globaliu prekiniu ženklu). Tenka pažymèti ir kitką, kad pirminis ryšys tarp architektūros ir tradicinių menų (skulptūros, tapybos ir pan.), atrodo, nyksta, tačiau tuo pat metu šiuolai-

\footnotetext{
4 V. Ozarinsko paroda (no) leader. Form, design, architecture. 200402 06-02 29. Prieiga per interneta: <http://www.cac.lt/en/ exhibitions/past/04>. T. Grunskis IN_plant. Prieiga per internetą: <www.grunskis.net/ kuryba $>$.
}

kinèje architektūroje (tiek metodinèje, tiek meninèje plotmėse) randasi įvairių šiuolaikinio meno pakraipų ir požiūrių, kurie neabejotinai veikia ir tai, kaip architektūra kuriama ir kaip apmąstoma. Šiuolaikine architektūra yra stipriai veikiama šiuolaikinių moderniausių menų pakraipų ir ideologiju - medijos menų, virtualybès ir kitų. Architektūrinè kūryba jau seniai yra tapusi tarpdalykine meno arba mokslo sinteze, nes jai būdingi ir vienos, ir kitos srities bruožai. Bendrai žiūrint, menas tampa moksliškesnis, o mokslas - meniškesnis, nes ir vienam, ir kitam reikalingas kūrybiškumas bei pagrịstumas. Nors meno ir mokslo pusiausvyra architektūrinejje kūryboje yra kintantis dalykas, tačiau aišku viena, kad ji tikrai seniai nebèra nei grynasis menas, nei grynasis mokslas, ir galop be sociokultūrinio pagrindo ir sąryšio su socialiniais reiškiniais šios dvi didelès sritys tebūtų grynasis amatas. Tačiau architektūrinè eksperimentika (arba dar kitaip - eksperimentinè architektūra) grynuoju amatu niekuomet nebuvo. Seniausi pavyzdžiai rodo, kad šiai sričiai priklauso kertiniai architektūrines ideologijas (kaip idejjų kaupinius) išreiškiantys, akumuliuojantys ir skatinantys kūriniai, kurie labai dažnai gerokai lenkia savo laikotarpius ne tik technologijos požiūriu, bet ir idejjų novatoriškumu (kad ir Tomo Moro utopija, kuri nèra architektūrinè-urbanistinè, bet socialiné utopija). Tokie eksperimentai yra tapę visuotiniu kultūriniu palikimu ir su laiku adaptuojami arba pritaikomi. Taigi, bendrai žiūrint, eksperimentinè architektūra skirtingais laikotarpiais suprantama ir mūsų ìvardijama kaip tokia a) dèl savo neigyvendinamumo ir idealizmo, dažniausiai realizavimas nèra jos tikslas; b) dèl formos ir metodo novatoriškumo, juos riboja ir lemia svarbus technologijos veiksnys. Ir viena, ir kita eksperimentinè architektūra plečia realios architektūros ribas bei sampratas ir jų idejos ilgainiui realizuojamos vienokiais ar kitokiais būdais vèliau.

Šiuolaikinė XX a. pabaigos - XXI a. pradžios architektūrinè kūryba bendruoju požiūriu eksperimentavo su forma ir metodu, tačiau abu šiuos dalykus veikè technologija (arba techninių galimybių raida ir vystymas). Technikos pažanga lèmé, kad daugelis anksčiau buvusių eksperimentinių idejjų šiandien tapo lengvai igyvendinamos, ir net tokių futuristinių architektūros grupių kaip Future systems ${ }^{5}$ - ar net Asypmtote ${ }^{6}$ - architektūriniai kūriniai nebèra techninis ar technologinis iššūkis. Todèl formos eksperimentika architektūroje šiandien nèra ypač įdomi. Kur kas įdomesni architektūros kaip metodo arba socialinio proceso eksperimentai, kuriuos naudojant organizuojami kolekty-

\footnotetext{
5 Plačiau žiūrèti: http://www.future-systems.com/ (tikrinta 2010 09)

6 Plačiau žiūrèti: http://www.asymptote.net/ (tikrinta 2010 09)
} 
viniai kūrybiniai ir socialinio dalyvavimo veiksmai, kurie nulemia architektūros fizinę formą bei išraišką (čia paminètinas architektų Dariaus Čiutos ir Viktoro Kormilcevo konkursinis darbas „11“ - miesto simbolis Dubajuje ${ }^{7}$, kurio architektūrinè ideja ir forma yra labai glaudžiai susieta su sociumu, kuris dalyvauja formuojant pastatą). Toks konceptualizmas architektūroje sukuria specifinị, ypatingą jos turinị ir padaro ją unikalią būtent dèl idèjinès sąsajos. Deja, kitų menų integravimas nèra privalomas ir labai būdingas tokiai kūrybai. Ji labiau siejasi su moksliškumu, ir ypač jei architektūriniame eksperimente laikomasi praktiškumo nuostatų i pastatą arba urbanistinę struktūrą. Arba tiesiog galutinè architektūros ar urbanistikos realizavimo funkcija išlieka kaip pagrindinis tikslas. Tačiau vis tiek labai dažnai tokie naujausių architektūrinių eksperimentų kūriniai yra labiau technologinis nei ideologinis iššǔkis. Reikia pažymėti, kad egzistavo (tikètina, kad tebeegzistuoja) ir kita eksperimentavimo pusè, kai kūrybinio eksperimento tikslas nèra pastato ar miesto struktūros realizacija, kai manifestų ar kitokia forma atskleidžiamos ir deklaruojamos kur kas didesnès vertybès ir (ar) problemos architektūrinès kalbos priemonemis. Čia visgi gali egzistuoti ir forma, ir metodas, tačiau eliminavus bet kokią kūrinio realizavimo funkciją, tokie eksperimentai igauna grynojo meno bruožų ir kultūrinio reiškinio savybių. Šie architektūriniai eksperimentai buvo pradèti septintojo dešimtmečio pabaigoje aštuntojo pradžioje su Team $10 \mathrm{ir}$ vèliau - Archigram architektūrinèmis grupèmis. Ypač Archigram kūriniams buvo būdingas kitų meninių kalbų ir priemonių integravimas ị architektūrinę kūrybą, siekiant išreikšti daugiau nei pastatas ar jo struktūra. Iš esmès buvo siekiama išreikšti naujas idèjas naujomis meninemis priemonemis, kurios iki tol nebuvo naudojamos architektūroje. Tuo metu architektai tikrai pakeite ir tai, kaip architektūra vaizduojama, ir tai, kaip ji kuriama. Jai labai būdingas tampa kinematografiškumas ar kinematografinis vaizdavimas (Betsky 2008) ir tai labiausiai matoma būtent Archigram grupès darbuose. Taigi grynai tradicinis architektūros vaizdavimas palaipsniui transformuojasi ir architektūrinès raiškos kalbinis arsenalas papildomas vizualiniais menais. Santykis su kitais - vizualiaisiais ir kino - menais čia glaudus dar ir dèl to, kad tradicinè architektūrinè kalba jai iškeltų uždavinių ir problemų neaprépia ir neaiškina. Kaip tik todèl buvo skolinamasi kitų meninių kalbų raiškos priemonių arba ieškoma alternatyvų.

Taip pat reikia pažymèti, kad vèlesnių, jau mūsų laikų, ir ypač dešimtojo XX a. dešimtmečio architek-

7 Plačiau žiūrèti: www.aarchitektai.lt (tikrinta 2010 09) tūrinių eksperimentų tarpdalykiškumas paịvairino architektūrinę kūrybą meninès kalbos aspektu. Tai suteike jai papildomų priemonių bei sustiprino jos sąryšs su kultūriniu kontekstu (kad ir koks jis būtų) ir privertė problemų laukus išplèsti kur kas plačiau nei viena konkreti profesija

\section{Apibendrinimas}

Iškiliausi architektūrinių eksperimentų pavyzdžiai patvirtina, kad architektūrinè kūryba jau seniai yra igavusi kultūrinio reiškinio, kuris yra glaudžiai susijęs su visuomene, bruožų. Kultūros ir jos raiškos formų plotmè eksperimentinëje architektūroje tampa vis aktualesnè ir reikšmingesnè (ypač sąsajos su jomis).

Meniniai ir moksliniai eksperimentai, nors šiuolaikiniame architektūrinių praktikų diskurse turi bendrumų, iš esmès tiek prielaidos, tiek proceso, tiek ir rezultato požiūriu labai skiriasi. Tarpdalykinis aspektas, kuris yra būdingas šiuolaikiniam meniniam eksperimentui, meną ir mokslą suartina. Labai dažnai naujausios meno rūšys skolinasi mokslinius duomenis ar idejjas, produktyviai jas interpretuoja bei išreiškia ir naudoja grynai meninei kūrybai.

Architektūrinio eksperimentavimo samprata kaip vientisas konceptas kol kas neegzistuoja. Tegalima nusakyti bendruosius požymius ir bruožus, kurie padètų apibūdinti architektūrinị kūrinị kaip eksperimentinị. Tai a) idealistine pakraipa ir b) labai aktyvus inovacijos elementas.

Taip pat konstatuotina, kad skirtingu laikotarpiu eksperimentinei architektūrai yra būdingas skirtingas santykis su kitais menais. Aptartos šeštojo-aštuntojo $\mathrm{XX}$ a. dešimtmečių architektūrinès eksperimentinès praktikos akumuliavo ir labai produktyviai eksploatavo kitu - vizualių (ir ne tik) - meno šakų kalbą. Kartu reikia pripažinti, kad su tradicinèmis fundamentaliomis meno šakomis, tokiomis kaip skulptūra ir tapyba, tokio glaudaus santykio nebebuvo. Šiuolaikinè - XXI a. pradžios - eksperimentiné architektūra tokio glaudaus ryšio su tradiciniais menais nebeturi. Tačiau taip pat reikia pripažinti, kad šiuolaikiniai naujausi su medijomis susiję menai architektūrinę kūrybą stipriai veikia tiek formų, tiek sampratos požiūriu.

Bendrai šiuolaikinè (XXI a. pr.) architektūrinè kūryba (tiek pastatų architektūra, tiek urbanistika) tampa socialesnè. Eksperimentas čia yra mažiau meniškas ar vertingas kaip grynas meno kūrinys tradicine prasme. Mažiau eksperimentuojama vien su forma ir labiau - su procesu ir tada forma. Nors kuriami ir deklaruojami naujausi architektūriniai įvaizdžiai yra abstraktesni ir universalesni, tačiau jie yra kur kas lengviau igyvendinami nei anksčiau (šiuolaikinès technologijos tai 
leidžia). Dèl šios priežasties yra gana sunku nubrèžti aiškią ribą tarp grynai idealistinès ir realistinès eksperimentinès architektūros, nes tai, kas dar neseniai buvo vizija, šiandien gali būti labai nesunkiai tgyvendinama. Ar tai reiškia, kad eksperimentai yra labiau socialūs ir ne tokie kūrybingi? Tikriausiai ne. Tiesiog kūrybiškumas yra transformuojamas ir igauna naujas išraiškas.

\section{Literatūra}

Betsky, A.; Gossel, P. 2007. UN Studio: Architecture for the Digital Age (Basic Architecture). Taschen.

Betsky, A. 2008. Experimental Architecture: a Short Introduction, Experimental Architecture. Architecture beyond building 3: 6-16. Bienalès katalogas.

Betsky, A; Adigard, E. 2000. Architecture Must Burn. A manifesto for an architecture beyond building. London: Thames and Hudson.

Duboy, Ph. 1986. Lequeu: An Architectural Enigma. Cambridge, MA: MIT Press.

Field, M. 2006. Future Systems. London: Phaidon.

Fischer, T. R. 2000. In The Scheme of things. Alternative thinking on Practice of Architecture. Mineapolis, London: University of Minnesota press.

From Control to Design. Parametric/Algorithmic Architecture. 2008. T. Sakamoto, A. Ferre, M. Kubo (Eds.). Barcelona, New York: Actar.

Hill, J. 2006. Immaterial Architecture. Routledge, London and New York.

Jencks, Ch.; Kropf, K. (Eds.). 1997. Theories and Manifestoes of Contemporary Architecture. Bath: Academy Editions.

Jodidio, Ph. 2009. Zaha Hadid: Complete works 1979-2009. Taschen.

Kaufmann, E. 1952. Three Revolutionary Architects: Boullée, Ledoux, and Lequeu. Philadelphia: American Philosophical Society.

Knack, U.; Klein, T. 2008. The Future Envelope 1. A Multidisciplinary approach. Amsterdam: IOS Press and the Authors.

Knack, U.; Klein, T. 2009. The Future Envelope 2. Architecture. Climate. Skin. Amsterdam: IOS Press and the Authors.

Koolhaas, R.; Mau, B.; Werlemann, H.; Sigler, J. 1995. S, M, L, $X L$. New York: Monacelli Press.

Le Corbusier. 1986. Towards a New Architecture. New York: Dover Publications.

Le Corbusier. 1987. The City of To - Morrow and Its Planning. New York: Dover Publications.

Ledoux, C. N. 1804. L'architecture considérée sous le rapport de l'art, des moeurs et de la législation. Tome premier. Paris.

Lemagny, J. C. 2002. Visionary Architects: Boullée, Ledoux, Lequeu. Los Angeles: Hennessey \& Ingalls.

Leopold, C. 2005. Experiments on Relation between Geometry, Architecture and Music, Journal for Geometry and Graphics 9(2): 169-179.

Miles, M. (Ed.). 2004. Urban Avant-gardes. Art, Architecture and Change. Routledge, London and New York.

Mitchel, W. J. 2003. Me++. The Cyborg Self and Network City. Cambridge, MA: MIT Press.
Mönninger, M.; Gössel, P. 2010. CoopHimmelb(l)au. Complete works. Taschen books.

More, T. 2003. Utopia. London: Penguin books.

MVRDV. 1999. KM3 Excursions on Capacities. Barcelona: Actar.

Perouse De Montclos, J. M. 1974. Étienne-Louis Boullée (1728-1799: Theoretician of Revolutionary Architecture). George Braziller.

Powley, M. 1994. Future Systems. The Story of Tomorrow. London: Phaidon.

Rattenbury, K. (Ed.). 2005. This is not Architecture. Media Constructions. Routledge, London and New York.

Tarptautinių žodžių žodynas. 1985. Vilnius: Vyriausioji enciklopedijų redakcija.

Terzidis, K. 2006. Algorithmic Architecture. Great Britain: Architectural Press.

Tracing Eisenman - Peter Eisenman Complete Works. 2006. C. C. Davidson (Ed.). Random House.

Traganou, J.; Mitrasinovic, M. 2009. Travel, Space, Architecture. Farnham, Burlington: Ashgate Publishing.

Verb Conditioning. 1999. A. Ferré, I. Hwang, J. Salazar, T. Sakamoto, A. Tetas, M. Kubo, R. Prat (Eds.). Barcelona: Actar.

Verb Connection. 2005. A. Ferré, M. Kubo, R. Prat, T. Sakamoto, A. Tetas (Eds.). Barcelona, New York: Actar.

Verb Crisis. 2008. M. Ballesteros, A. Ferré, I. Hwang, M. Kubo, T. Sakamoto, A. Tetas, R. Prat (Eds.). Barcelona, New York: Actar.

Глазычев, В. Л. 2002. Архитектура. Энииклопедия. Москва: Астрель, Дизайн. Информация. Картография. АСТ.

\section{UNDERSTANDING THE CONCEPT OF CREATIVE EXPERIMENT IN ARCHITECTURE}

\section{T. Grunskis}

Abstract. While analysing creative experiments in architecture, one finds a number of different phenomena and examples, not so easy to discuss in a more or less systematic way. These phenomena and results, in one or another way related to experimental architecture, can hardly be defined by a single category and, as shown by the history of architecture, have become one of its driving forces contributing to the development of architecture in the course of time.

The issue of the concepts of architectural experimentation on the whole is important and urgent in two aspects. First of all, such concepts are used in attempting to formulate basic architectural and cultural declarations, consequentially applied in forming and proclaiming different political creeds (usual practice of international architectural biennales and expo exhibitions). Secondly, their cultural value is of key importance too, as the ideas and thoughts expressed through the experimental creation often convey social aspects and states, also the idea, how architecture is understood during a specific period of time and the role given to it by society. Finally, as architecture is a language used by society to convey its socio-cultural status and values, the experimental architectural creation can be significant, although often ignored, in architectural practice. 
The most outstanding examples of architectural experiments confirm that architecture as artistic creation has long ago gained certain features of a cultural phenomenon, which eventually has become closely connected to society. Thus the area of culture and forms of its expression has becoming more and more relevant and significant to architectural experimentation.

Although artistic and scientific experiments have certain similarities within contemporary discourse of architectural practices, they still differ a lot in the aspects of their backgrounds, processes and even results. But still, the interdisciplinary aspect, common to contemporary artistic experimentation, draws art and science closer together. Fairly often, peculiar new forms of art borrow scientific data or ideas interpreting, expressing and using them effectively to make pure art. The concept of architectural experimentation still does not exist as an integral concept. Only a few general features and attributes can be named as helping to define the architectural phenomenon as an experimental one. These are: (a) the idealistic trend and (b) very active element of motivation.

It is also noteworthy that looking retrospectively, within different epochs the architectural experimentation had different relationship with other arts. The discussed in the article experimental practices of architecture in the 1950-ies - 1970-ies accumulated and effectively operated the languages of other visual - and not only - arts. Although, at the same time it should be admitted that they did not have the same close relationship to traditional, fundamental arts, such as sculpture and painting. So does the contemporary, the $21^{\text {st }}$ century, architectural experimentation - it no longer has closer connection to traditional arts. Although it has to be admitted that the most recent, media-related arts influence experimental architecture on the levels of its forms as well as concepts.

In general, the architectural creation at the beginning of the $21^{\text {st }}$ century (both building architecture and urban planning) is getting more and more social. The experiment in such creation is less artistic or valuable as pure art in the traditional sense. Fewer experiments are made on the form only, but rather on the process itself and then - the form. Although the most innovative architectural images being developed and declared are getting more abstract and universal, they are easier to implement than before (due to the most advanced technologies). So, it is not so simple to draw a dividing line between purely idealistic and realistic experimental architecture, because what was just a vision not so long ago, today can be easily realized. Does it mean that experiments have become more social and less creative? Probably, not. Most likely, it's because creativity has become transformable and gained new ways of expression.

Keywords: experimental architecture, creative experiment, concept.

\section{TOMAS GRUNSKIS}

Architect, PhD, Assoc. Prof., Dept of Architectural Fundamentals and Theory, Vilnius Gediminas Technical University, Pylimo g. 26/Traku g. 1, 01132 Vilnius, Lithuania.

E-mail:grunskis@gmail.com.Web:www.grunskis.net

Publications: author of 58 articles in popular professional and scientific magazines. Research interests: urban morphology and anthropology, urban design and public space formation, interdisciplinary research. Projects: author and co-author of several winning projects in urban design and architecture. 